\title{
Exposure Planned Occurrence
}

National Cancer Institute

\section{Source}

National Cancer Institute. Exposure Planned Occurrence. NCI Thesaurus. Code C113353.

An instance of an exposure event or incident that is intended to take place. 